IJJM

Ilomata International Journal of Management

P-ISSN: 2714-8971; E-ISSN: 2714-8963

Vol. 1 No. 2 March 2020 pp. $78-82$

https://www.ilomata.org/index.php/ijim

\title{
Build A Web-Based E-Commerce Information System Using Content Management System (CMA) at Djuwariyah Accountant Service Office
}

\author{
Rafi Ardo, Mohamad Hasanudin, Afiat Sadida, Musyafa Al Farizi \\ Accounting Department, Semarang state polytechnic \\ Correspondent: muhammadhasanudin1976s@gmail.com
}

Submitted: February $19^{\text {th }}, 2020 \quad$ Revised: March $12^{\text {th }}, 2020 \quad$ Published: March $30^{\text {th, }} 2020$

\begin{abstract}
The purpose of this research is to design and build a web-based e-commerce information system using a Content Management System (CMS) that can provide informative information, make transactions online, and expand market coverage. The system has built using CMS WordPress. The method used in system development is a prototype method with the system modeling language used is Unified Modelling Language (UML). The results obtained are a web company that provides informative information about the company profile and can conduct online service orders transactions.
\end{abstract}

Keywords: Office of accountant Services, E-Commerce, CMS, prototype

\section{INTRODUCTION}

The role of economics and accounting is crucial in a business. Accounting has a function to improve the transparency of the quasi report needed by economic actors in the business world as a basic guideline in financial decision making. The Accounting Firm provides accounting services for users carried out by certified professionals. It has licenses, branches, codes of conduct, and supervision from the Government and IAI that must be recorded on the List of State Accountants (RNA) so that they have permission from a state-licensed accountant. The existence of KJA has regulated by the Minister of Finance regulation No. 216 / PMK. 01/2017. KJA Djuwariah is an accountant service office located on Jl. Darat Nipah 3 No. 215A, Dadapsari Village, North Semarang district.

Based on the results of the evaluation conducted by the company in April 2019, knowing that the company's weakness is in the market coverage that is still in the dominance of Semarang domicile. The marketing system done by KJA Djuwariyah has only been through the spread of business cards at certain events. Clients order services by contacting the contact person listed on the company's business card. The transaction system to order services is still manually, so the client must come directly to KJA.

Based on the company's problem that has outlined, KJA Djuwariyah needs web-based ecommerce that aims to expand market reach, providing information about KJA Djuwariyah's profile, and can make online booking transactions. Ecommerce is a transaction between the seller and the buyer through online media using the Internet network. 
Build A Web-Based E-Commerce Information System Using Content Management System (CMS) at Djuwairiyah Accountant Service Office

Ardo, Hasanudin, Farizi

\section{METHOD}

This research uses applied research approaches. The study conducted at the office of Djuwariyah Accountants, who have an address on Jalan Darat Nipah No. 251 A, Dadapsari, North Semarang. The research aims to design and to build a Web-based e-commerce application. Enterprise Web creation has created using a content management system that can be used easily by the Web administrator of the company.

The data in this study use primary data and secondary data. Primary Data obtained through interviews with the Accountant Service office and observed direct observation of the research object. The secondary data is information taken from the company's profile, books, journals, scientific articles, Internet sites as a review of this research writing library. Data types based on their nature differentiated into qualitative data and quantitative data. Qualitative Data In this study is a general overview of the company, its history, its organizational structure, and its respective duties and authorities. The quantitative data needed in this study relates to the service tariff of the KJA Djuwariyah.

In this research, the techniques used in obtaining the necessary data are by observing, interviewing, and library studies. The method of system development used in this research is using prototype methods. According to Sajja (2017:82), There are four phases in the prototype method, namely identification of known terms, building working models, prototype trials, and prototype review.

\section{RESULT AND DISCUSSION}

In conducting the identification of the running system, researchers use PIECES analysis (performance, information, economics, control, efficiency, service) to determine the weaknesses of old systems. The following is a comparison between current methods applied by companies with new Systems analyzed using PIECES analysis.

Table 1. Analysis of PIECES

\begin{tabular}{|l|l|}
\hline \multicolumn{1}{|c|}{ Analysis Type } & \multicolumn{1}{|c|}{ Present System } \\
\hline Performance & $\begin{array}{l}\text { As long as conveying information about the } \\
\text { Company has done through the spread of business } \\
\text { cards at certain events. }\end{array}$ \\
\hline Information & $\begin{array}{l}\text { The information contained in the business card } \\
\text { includes only the contact person. }\end{array}$ \\
\hline Economic & $\begin{array}{l}\text { The company estimates the cost to print business } \\
\text { cards, and the fees for following specific events. }\end{array}$ \\
\hline Control & $\begin{array}{l}\text { Transaction management has done by the } \\
\text { corporate Secretary and is known }\end{array}$ \\
\hline
\end{tabular}

Source: Primary Data, 2019

79 | Ilomata International Journal of Management

Vol. 1 No. 2 March 2020 
Build A Web-Based E-Commerce Information System Using Content Management System (CMS) at Djuwairiyah Accountant Service Office

Ardo, Hasanudin, Farizi

Analysis of the system needs to define the needs of the system built. Inbuilt a system that has just needed a device - a device that supports the creation of information system financial statements, needs that need to be prepared to include:

1. Hardware requirements in establishing an e-commerce informer system are required hardware that is capable of supporting the operation of the system, namely a laptop device.

2. The need for software used to run an e-commerce information system consists of a Windows operating system 7/8/10, Web browser, plugin, PDF, and CSV reader.

3. Information needs analysis needs the information functioning to outline the information required for system developers. The system required information is service data information, client identity, and report data.

4. User needs system information built has two types of access rights for the security of internal control consisting of admins and clients.

System feasibility analysis has done to define the feasibility of the e-commerce information system to be implemented. The feasibility analysis examining the aspects of the proposed method includes:

1. Technical possibility: The proposed system deserves to be applied to the office of the accountant Services Djuwariyah. The e-commerce information system built using Web service technology so that customers can access it through a computer or smartphone.

2. Operational eligibility: The e-commerce information system to be applied to the office of the Djuwariyah Accountant service is said to be feasible due to the following factors:

a. The built-in information system can provide company information to the client.

b. The integrated system can make it easier to record the income received by the company.

c. The system that built is applying according to the needs of the company.

3. Economic feasibility: economic feasibility analysis is required to measure how fast the investment will return. Calculation of economic viability has done by calculating Payback Period (PP) and Return on Investment (ROI) and Present Net Value (NPV).

4. Legal eligibility: The supporting application used in the creation of this system is an open-source application that is available for free on the official web so that in terms of the form is no indication of legal violations.

5. Social Eligibility: Users of assisted systems in the processing of data orders and services revenue companies, in addition to which users are more supporting information with the speed and accuracy of the data provided.

The next step in the prototype method is to build a working model using the requirements that have accumulated. This stage consists of three parts that are designing the 
Build A Web-Based E-Commerce Information System Using Content Management System (CMS) at Djuwairiyah Accountant Service Office

Ardo, Hasanudin, Farizi

working model using UML and interface planning. The standard modeling used in building working models is the Unified Modelling Language (UML). The UML will use in this research, i.e., Use Case Diagram, Activity Diagram, Sequence Diagram, and Deployment Diagrams.

User Acceptance Testing (UAT) aims to verify that the solutions made in the proposed system are appropriate to the needs of the user. User Acceptance Testing conducted on the thesis test on 22 August 2019. The system examiner consists of a single representative from the industry (user) and the two Faculty of accounting department of Semarang Polytechnic who are skilled and competent in the field of accounting information systems. In this test acquired some system modifications as follows.

1. Add a deployment diagram aimed at demonstrating the communication relationship between the hardware components with the software.

2. Add a notification to the client when the service processed and the job has done.

3. They are adding access rights for accountants to obtain information on the order of services entered through a Web-based e-commerce information system.

\section{CONCLUSION}

The design of information systems of Web-based e-commerce information systems successfully implemented by Using a WordPress Content management system (CMS). The client can conduct the order transaction services according to the needs of the corporation because the Web provides informative information for the client. The Admin can conduct the management and supervision of all online transaction activities and can be.

The design of information systems of Web-based e-commerce information systems successfully implemented by Using a WordPress Content management system (CMS). The client can conduct the order transaction services according to the needs of the corporation because the Web provides informative information for the client. Admin can perform management and supervision of all online transaction activities and can make changes to a Web page view.

\section{REFERENCE}

Sajja, Priti Srinivas. (2017). The essence of System Analysis and Design: A Workbook Approach. Singapore: Springer Nature Singapore Pte Ltd.

Aribawa, Dwitya. (2016). "E-Commerce Strategic Business Environment Analysis in Indonesia." International Journal of Economic and Financial Issues, 6 (6).

Dewangga Anjarkusuma, Bambang Soepeno. (2014). "Penggunaan Aplikasi CMS Wordpress untuk Merancang Website sebagai Media Promosi pada Maroon Wedding Malang." Jurnal Akuntansi, Ekonomi, dan Manajemen Bisnis, 2 (1).

Fatta, Hanif Al. (2007). Analisis dan Perancangan Sistem Informasi. Yogyakarta: Andi.

Febriantoro, Wicaksono. 2018. "Kajian dan Strategi Pendukung Perkembangan E- Commerce Bagi UMKM di Indonesia.” Jurnal Manajerial, 3 (5).

Krismiaji. (2010). Sistem Informasi Akuntansi. Yogyakarta: UPP AMP YKPN.

Nair, Kiran, S. (2017). "Impact of E-Commerce on Global Business and Opportunities - a Conceptual Study." International Journal of Advanced Engineering and Management Research, 2 (2). 
Build A Web-Based E-Commerce Information System Using Content Management System (CMS) at Djuwairiyah Accountant Service Office

Ardo, Hasanudin, Farizi

Kementrian Keuangan. (2017). Peraturan Menteri Keuangan No.216/PMK.01/2017. 2019. www.jdih.kemenkeu.go.id/fullText/2017/216 PMK.0 1 2017.

Pratama, I Putu Agus Eka. (2014). Sistem Informasi dan Implementasinya. Bandung: informatika.

Rohilla, Neeraj. (2017). "Content Management System For E-Commerce Website Development.” International Journal of Engineering Science and Research Technology, 6 (7).

.'Web Content Management System (WCMS): A Need." International Journal of Engineering and Computer Science, 6 (6).

Romney, Marshall B, Paul John Steinbart. (2014). Sistem Informasi Akuntansi: Accounting Information Systems (Edisi 13), Prentice-Hall.

Sajja, Priti Srinivas. (2017). The essence of System Analysis and Design: A Workbook Approach. Singapore: Springer Nature Singapore Pte Ltd.

Shahriari, Shahrzad, Mohammadreza Shahriari, Saeid Gheiji. (2015). "E-Commerce and It Impact on Global Trend and Market." International Journal of Research, 3 (4).

Sofian, Silvia. (2017). "Penerapan Sistem Informasi E- Commerce Berbasis Web (Studi Kasus Vendor Pernikahan)." JITEKH. 6 (2).

Srivastav, Manoj Kumar. (2014). "Web Content Management System." International Journal of Innovative Research in Advanced Engineering, 3 (3). 